\title{
National Undergraduate Medical Core Curriculum in Turkey: Evaluation of Residents
}

\author{
Iş11 İrem Budakoğlu¹, Özlem Coşkun ${ }^{1}$, Mehmet Ali Ergün² \\ 'Department of Medical Education, Gazi University Faculty of Medicine, Ankara, Turkey \\ ${ }^{2}$ Department of Medical Genetics, Gazi University Faculty of Medicine, Ankara, Turkey
}

Background: There is very little information available on self-perceived competence levels of junior medical doctors with regard to definitions by the National Core Curriculum (NCC) for Undergraduate Medical Education.

Aims: This study aims to determine the perceived level of competence of residents during undergraduate medical education within the context of the NCC.

Study Design: Descriptive study.

Methods: The survey was conducted between February 2010 and December 2011; the study population comprised 450 residents. Of this group, $318(71 \%)$ participated in the study. Self-assessment questionnaires on competencies were distributed and residents were asked to assess their own competence in different domains by scoring them on a scale of 1 to 10 .
Results: Nearly half of the residents reported insufficient experience of putting clinical skills into practice when they graduated. In the theoretical part of NCC, the lowest competency score was reported for health-care administration, while the determination of level of chlorine in water, delivering babies, and conducting forensic examinations had the lowest perceived levels of competency in the clinical skills domain.

Conclusion: Residents reported low levels of perceived competency in skills they rarely performed outside the university hospital. They were much more confident in skills they performed during their medical education.

(Balkan Med J 2014;31:23-28).

Key Words: Core curriculum, evaluation, medical education
A paradigm shift in educational priorities has occurred in medical teaching in recent years, as curricula have been developed at a national level in many countries (1-9). In Europe, Directive 2005/36/EC of the European Parliament declares that basic medical training shall comprise a total of at least six years of study or 5,500 hours of theoretical and practical training provided or supervised by a university (10). The American Association of Medical Colleges established the Medical Schools Objective Project (MSOP) whose goal was "to reach a consensus as to what skills medical students should possess at the time of graduation". According to MSOP, students should have the ability to perform routine technical procedures (11). Some medical schools in the United States have also implemented a number of key domains for the undergraduate medical curriculum (3).

Canada, on the other hand, developed CanMEDS in 2005; this defines competencies based on the roles that a medical practitioner performs. Traditionally, medical education has focused competence around core medical expertise. (7).
In Switzerland, the Joint Commission of the Swiss Medical Schools (SMIFK/CIMS) decided in 2000 to establish a national Catalogue of Learning Objectives for Undergraduate Medical Training (SCLO), which was adapted from the Dutch Blueprint and published in 2001 (12).

In Turkey, the National Core Curriculum (NCC) was developed in 2001-2002 to identify standards for medical degrees, stating what a graduate is supposed to know, able to do, and competent in, within the context of local needs and realities. These standards have been developed under the guidance of academics from around the country (13). Included in the NCC was the recommendation that students have the ability to know diagnosis and treatment or only recognise the Illness-Condition-Symptom or perform routine technical procedures, including venipuncture, inserting a nasogastric tube, etc.

Despite the fact that ten years have passed since the development of these standards, only a handful of studies have retrospectively evaluated the impact of the NCC $(14,15)$. In this 
study, we aimed to evaluate self-competency levels of residents when they graduated, regarding the curricula of their individual undergraduate education programs, based on the NCC.

\section{MATERIAL AND METHODS}

\section{Setting and study group}

This cross-sectional study was conducted at Gazi University Hospital between 2010 and 2011. Data were collected between May and November 2010. Questionnaires were distributed at every department of the University Hospital. A total of 455 residents were undertaking training at the hospital during that period and, of those, $318(71 \%)$ participated in the study.

\section{Data collection}

Residents were asked to provide demographic information and assess their own competence in different domains when they had graduated, according to the NCC's theoretical and procedural parts. Before gathering data, the researchers grouped 407 items of the theoretical part (Disease-Illness-Symptom list) of the NCC, under 14 body systems stated as in NCC. These are Respiratory, Circulation, Haematopoietic, Gastrointestinal, Endocrine, Genito-urinary, Perinatology/neonatology, Neurosensory, Musculoskeletal, Skin and soft tissue, Oncology, Multisystem infections, Emergency/intensive care, and Healthcare administration. The procedural section has 78 items listed in it, and these are grouped as skills that medical school graduates must learn and/or become competent in (13).

The study participants were asked to self-evaluate their competence in these parts when they had been graduated by scoring them on a scale of 1 (the worst) to 10 (the best). For example, "Please score your undergraduate theoretical education according to the systems listed below" or "Please score your undergraduate practical training according to the list presented below". The cronbach's alpha values of theoretical and procedural parts were 0.945 and 0.984 respectively. This study was supported by a grant from Gazi University in 2010 (Project No: 01/2010-48).

\section{Statistical analysis}

Data analyses were performed using Statistical Package for Social Sciences (SPSS), v.11.5 (SPSS Inc., Chicago, IL, USA). For the reliability analysis of Cronbach's Alpha value was calculated.

\section{RESULTS}

The average age of study participants was $28.5 \pm 0.2$. Of the participants, 190 (59.7\%) were female, 151 (47.5\%) were single, $195(61.3 \%)$ were studying in the internal medical field, $102(32.1 \%)$ were studying for a career in a surgical field, and $21(6.6 \%)$ of them were from basic medical sciences. The median year of graduation from undergraduate medical school was 2007. The residents graduated from 31 different medical schools in different regions of the country.

Of all of the residents surveyed, 158 (49.2\%) reported insufficient self-perceived competence in clinical skills (Figure 1). When self-perceived competence was evaluated based on the theoretical part of the curriculum, given as system/topic based, the highest score was for gastrointestinal medicine (7.8 \pm 1.6$)$ and the lowest score was $5.3 \pm 2.8$ for healthcare administration (Table 1).

In the procedural section, the highest scores for the self-evaluation of competency were attained for urinary catheter place-

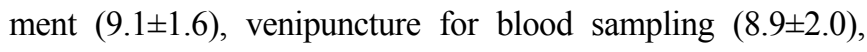
and blood pressure measurements $(8.9 \pm 1.6)$. The lowest scores were reported for determination of the level of chlorine in water

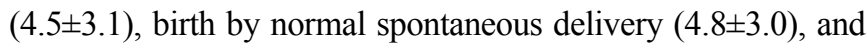
conducting forensic post-mortem examinations (4.9 \pm 3.0$)$. Of the 78 skills listed in this domain, $21(26.9 \%)$ received scores lower than 6 points. The scores are shown in Table 2 .

\section{DISCUSSION}

In Turkey and across the world, much effort has been made to improve the quality of medical education since the begin-

TABLE 1. Distribution of scores for competencies in theoretical part (on a scale of 1 to 10$)(n=318)$

\begin{tabular}{|c|c|}
\hline Systems & $\begin{array}{l}\text { Scores }[\text { Mean } \pm \text { SD } \\
\quad(\min -\max )]\end{array}$ \\
\hline 1. Respiratory & $7.5 \pm 1.8(1-10)$ \\
\hline 2. Circulation & $7.4 \pm 1.7(2-10)$ \\
\hline 3. Haematopoietic & $7.1 \pm 1.9(1-10)$ \\
\hline 4. Gastrointestinal & $7.8 \pm 1.6(1-10)$ \\
\hline 5. Endocrine & $7.5 \pm 1.7(2-10)$ \\
\hline 6. Genito-urinary & $7.0 \pm 1.9(2-10)$ \\
\hline 7. Perinatology/neonatology & $6.5 \pm 2.2(1-10)$ \\
\hline 8. Neurosensory & $6.9 \pm 1.9(2-10)$ \\
\hline 9. Musculoskeletal & $7.1 \pm 1.9(1-10)$ \\
\hline 10. Skin and soft tissue & $7.3 \pm 1.8(1-10)$ \\
\hline 11. Oncology & $6.5 \pm 2.2(1-10)$ \\
\hline 12. Multi system infections & $6.8 \pm 1.9(1-10)$ \\
\hline 13. Emergency/intensive care & $6.7 \pm 2.3(1-10)$ \\
\hline 14. Healthcare administration & $5.3 \pm 2.8(1-10)$ \\
\hline
\end{tabular}

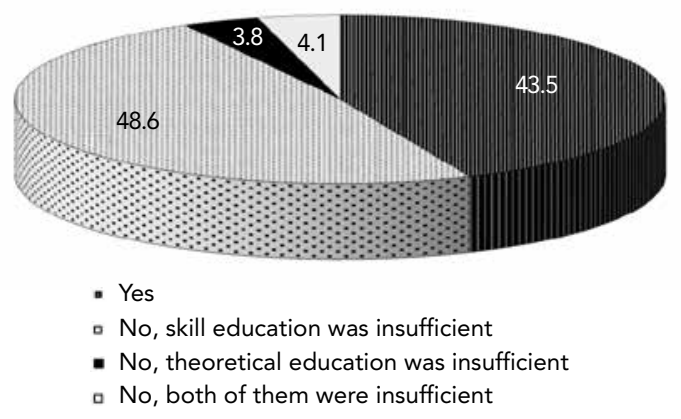

FIG. 1. Did you feel competent on diagnosis and treatment of a patient when you graduated? (\%) 
TABLE 2. Distribution of scores for competencies in procedural domain (on a scale of 1 to 10$)(\mathrm{n}=318)$

\begin{tabular}{|c|c|}
\hline Subjects & Scores $[$ Mean \pm SD, (min- \\
\hline \multicolumn{2}{|l|}{ Taking history, planning treatment, records and reporting } \\
\hline 1. History taking, treatment planning, record keeping and reporting findings & $8.3 \pm 1.6(2-10)$ \\
\hline 2. Evaluating mental status, obtaining a psychiatric history & $7.4 \pm 1.9(2-10)$ \\
\hline 3. Putting together a patient file & $8.3 \pm 1.7(2-10)$ \\
\hline 4. Appropriate record keeping and reporting & $7.8 \pm 1.8(2-10)$ \\
\hline 5. Correct, appropriate and legible prescription writing & $8.0 \pm 2.0(1-10)$ \\
\hline 6. Writing an epicrisis report & $7.9 \pm 2.0(1-10)$ \\
\hline 7. Appropriate referral of patients & $6.8 \pm 2.3(1-10)$ \\
\hline 8. Writing a forensic report & $5.6 \pm 2.7(1-10)$ \\
\hline \multicolumn{2}{|l|}{ General and local physical examination } \\
\hline 9. Skin examination & $7.3 \pm 2.0(1-10)$ \\
\hline 10. Head and neck, ENT examination & $7.2 \pm 1.9(1-10)$ \\
\hline 11. Eye and fundus examination & $5.7 \pm 2.6(1-10)$ \\
\hline 12. Respiratory system examination & $8.0 \pm 1.6(2-10)$ \\
\hline 13. Measuring and observing body temperature & $8.6 \pm 1.7(1-10)$ \\
\hline 14. Taking blood pressure & $8.9 \pm 1.6(1-10)$ \\
\hline 15. Cardiovascular system examination & $7.9 \pm 1.7(1-10)$ \\
\hline 16. Abdominal examination & $8.3 \pm 1.5(4-10)$ \\
\hline 17. Neurological examination & $7.6 \pm 1.7(3-10)$ \\
\hline 18. Musculoskeletal examination & $7.3 \pm 2.0(1-10)$ \\
\hline 19. Psychiatric evaluation & $6.7 \pm 2.2(1-10)$ \\
\hline 20. Breast and auxiliary region examination & $7.5 \pm 2.0(1-10)$ \\
\hline 21. Digital rectal examination & $7.0 \pm 2.3(1-10)$ \\
\hline 22. Urological examination & $6.3 \pm 2.4(1-10)$ \\
\hline 23. Gynaecological examination & $6.2 \pm 2.5(1-10)$ \\
\hline 24. Evaluation of the pregnant & $5.9 \pm 2.4(1-10)$ \\
\hline 25. Evaluation of paediatrics and newborns & $6.3 \pm 2.3(1-10)$ \\
\hline 26. Forensic examination of the dead & $4.9 \pm 3.0(1-10)$ \\
\hline \multicolumn{2}{|l|}{ Laboratory tests and other related procedures } \\
\hline 27. Following principles of working with a biological material & $6.0 \pm 2.5(1-10)$ \\
\hline 28. Preparing direct material for microscopic evaluation & $6.1 \pm 2.5(1-10)$ \\
\hline 29. Transferring 5 laboratory specimens to a laboratory under appropriate conditions & $6.7 \pm 2.4(1-10)$ \\
\hline 30. Filling out request forms for microbiological/pathological/radiological examinations & $7.7 \pm 2.3(1-10)$ \\
\hline 31. Using a microscope (gram evaluation, etc.) & $7.0 \pm 2.3(1-10)$ \\
\hline 32. Performing complete blood counts and peripheral smears & $6.4 \pm 2.6(1-10)$ \\
\hline 33. Measuring sedimentation & $5.7 \pm 2.8(1-10)$ \\
\hline 34. Evaluating bleeding and clotting times & $5.9 \pm 2.7(1-10)$ \\
\hline 35. Performing complete urinalysis (including microscopic evaluation) & $5.8 \pm 2.7(1-10)$ \\
\hline 36. Performing faecal smears and microscopic evaluation & $5.5 \pm 2.9(1-10)$ \\
\hline 37. Evaluating vaginal samples & $5.2 \pm 2.9(1-10)$ \\
\hline 38. Measuring blood sugar using a glucometer & $8.8 \pm 1.8(1-10)$ \\
\hline 39. Measuring lung function using a peak-flow meter & $5.7 \pm 3.0(1-10)$ \\
\hline 40. Performing an electrocardiogram (ECG) & $8.5 \pm 2.0(1-10)$ \\
\hline 41. Performing decontamination, disinfection, sterilization, and antisepsis & $7.2 \pm 2.3(1-10)$ \\
\hline 42. Transporting infectious samples and performing inoculation & $6.3 \pm 2.7(1-10)$ \\
\hline 43. Obtaining water and food samples & $5.2 \pm 3.0(1-10)$ \\
\hline 44. Performing water disinfection & $5.0 \pm 2.9(1-10)$ \\
\hline 45. Determining the chlorine level in water & $4.5 \pm 3.1(1-10)$ \\
\hline \multicolumn{2}{|l|}{ Invasive procedures } \\
\hline 46. Starting intravenous lines & $8.4 \pm 2.3(1-10)$ \\
\hline 47. Obtaining venous/capillary blood samples & $8.9 \pm 2.0(1-10)$ \\
\hline 48. Inserting a urinary catheter & $9.1 \pm 1.6(1-10)$ \\
\hline 49. Performing blood transfusions & $6.4 \pm 3.1(1-10)$ \\
\hline 50. Administering local and systemic medications, giving shots, and PPD skin tests & $7.4 \pm 2.5(1-10)$ \\
\hline 51. Preparing medications to be administered & $7.4 \pm 2.6(1-10)$ \\
\hline 52. Performing insulin injection techniques & $7.5 \pm 2.6(1-10)$ \\
\hline 53. Obtaining cultures of related infections & $8.3 \pm 2.0(1-10)$ \\
\hline 54. Performing enema & $7.4 \pm 2.7(1-10)$ \\
\hline
\end{tabular}




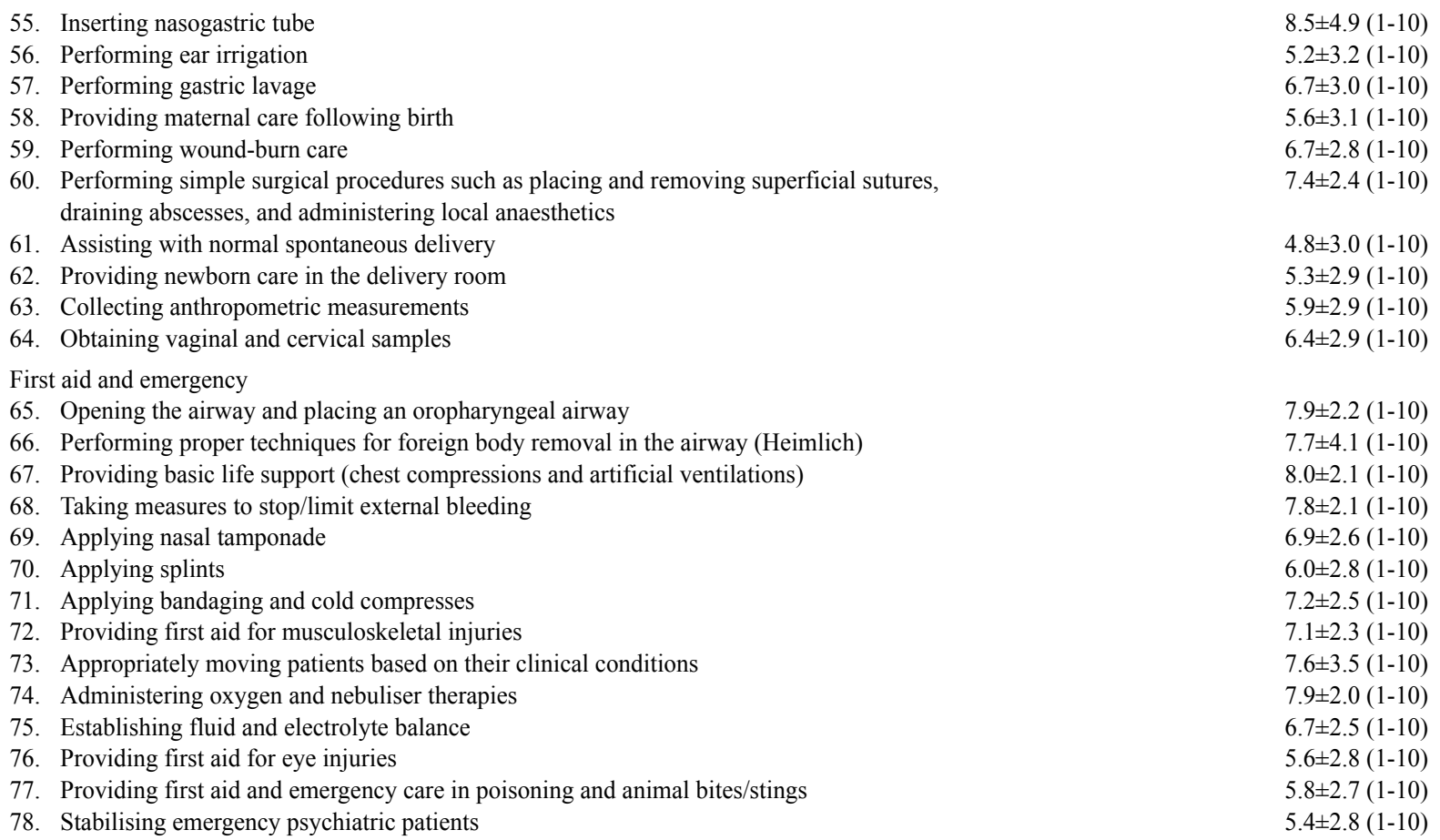

SD: Standard deviation

ning of the $21^{\text {st }}$ century. Ten years after the establishment of the NCC, almost all of the medical schools in Turkey follow the principles defined by it when delivering their curricula (16). In our study group, the median year of graduation was 2007. It was clear that the NCC was utilised by the majority of programs at universities from which the participants graduated.

Nearly half of the residents still feel insufficient selfperceived competence in clinical skills. Similarly, a study conducted in Ireland reported that $91 \%$ of the graduates considered that they were not prepared for all the skills/competencies needed as an intern (17).

In our study, we found that the lowest score was given for healthcare administration; however, according to the European Core Curriculum:

- graduates should know the structure and functions of the healthcare system, the role of the doctor and other professions in the healthcare system,

- graduates should know their legal obligations regarding patients' treatment and records,

- graduates should have sufficient knowledge about the information technology used by the healthcare system in which they are working,

- graduates should know how prevention programs can improve the health of the community and keep their knowledge up-to-date (18).

Around the world, the teaching of healthcare administration to students as part of the medical school curriculum has been debated for the past 10-15 years. Doctors state that ad- ministration is not their responsibility and constitutes an obstacle to good clinical practice (19). Even though this topic has been integrated into the medical school curriculum in Turkey since the 1960s, it is unlikely that students see it as a key topic, since it is not seen as part of medical practice and its importance is not appreciated during the undergraduate years.

Self-perceived competence was best in urinary catheter placement, venipuncture for blood sampling, and blood pressure measurement; the lowest levels of competence were reported for determination of the level of chlorine in water, performing normal spontaneous delivery, and conducting forensic post-mortem examinations. According to 62 Associate Deans for Academic Affairs from the USA, 82\% of them think that medical students should be proficient in venepuncture, while $71 \%$ of them think they should be proficient in the placement of a urinary catheter (71\%) (20). In 46 out of 55 medical schools where teaching took place at the universities' own training and research hospitals, "Clinical Skills Education" (CSE) was taught from the early years of medical education (16) as a result of humanistic approach in medical education. Some of the skills with the highest perceived competency scores were those taught as part of CSE programs.

In a study investigating the proficiencies of newly graduated doctors, the skills noted as being performed more than five times within the first year of junior employment were wound suturing, urinary catheter placement and venipuncture (11). In another study, students who performed a skill more than twice achieved a self-confidence score in that particular skill of 4.2 
out of 5 on average (21). From a study which was designed as semi-structured interview, a newly qualified doctor stated "if I hadn't done that (any kind of clinical skills) [...] I would have really struggled". As the comment from this study demonstrates, the practice of 'doing', as opposed to just observing, is very important (22). Although developed as part of the curriculum, the skills receiving the lowest scores were either never practiced or insufficiently practiced by the students. In order to improve competency in certain skills, the curricula must indicate the levels of competency attained at different stages of training and must be time flexible $(23,24)$.

The NCC should be developed, based on the needs and realities of the population. Updating the curricula to take account of current developments is also an important aspect of improving the quality of medical education. For example, while chlorine analysis in water used to be regularly performed at primary care healthcare practices in Turkey when the NCC was being developed, it is now performed at public health laboratories due to recent changes in legislation (25).

Although nearly all of the interns (91.8\%) found themselves insufficient regarding some of the procedural skills (26), they spent most of their time studying the theoretical components of the medical school curriculum because of the national specialty exam. This can be seen as a factor that limits the effectiveness of clinical training.

A major limitation of our study was that memory was an important factor in the residents' self-perceived competence at different skills, as is often found with retrospective studies. We questioned the study participants about the learning which took place during the undergraduate years of medical education, so their memory is likely to have influenced their answers. However, the influence of memory may have been limited by the way in which questions were targeted in the comprehensive data form. The results may also have been influenced by the uneven distribution of undergraduate medical schools by region. Since ours was a descriptive study, the information gathered from graduates from 31 different medical schools allowed for the nationwide generalisation of results.

In conclusion, medical school graduates have adequate levels of self-perceived competence in procedural skills urinary catheter placement, venipuncture for blood sampling, and blood pressure measurement, but they report poor competence in skills determination of the level of chlorine in water, birth by normal spontaneous delivery, and conducting forensic post-mortem examinations. Increasing the intensity of skills training in the pre-clinical and clinical periods of undergraduate medical education may increase the competency level of medical students. Training facilities for medical students outside medical schools with qualified educators and trainers may also help to increase the level of competency of medical school graduates.
Ethics Committee Approval: This study was approved by the Editorial Board of the Balkan Medical Journal depending on the COPE's document "Guidance for Editors: Research, Audit and Service Evaluations".

Informed Consent: Informed consent was obtained from participants of this study.

Peer-review: Externally peer-reviewed.

Author contributions: Concept - I.B., O.C.; Design - I.B.; Supervision - I.B., O.C.; Resource - I.B., O.C., M.A.E.; Materials - I.B., O.C., M.A.E.; Data Collection \&/or Processing - I.B., O.C., M.A.E; Analysis \&/or Interpretation - I.B., O.C; Literature search - I.B.; Writing - I.B., O.C, M.A.E; Critical Reviews - I.B., O.C, M.A.E.

Acknowledgements: The authors would like to thank to the participants of the study.

Conflict of Interest: No conflict of interest was declared by authors.

Financial Disclosure: This study was supported by a grant from Gazi University (Ankara, Turkey) in 2010 (Project No: 01/2010-48).

\section{REFERENCES}

1. Huon S, Giuseppe F, Pietro G, Eugenio G, Andrea L, Vincenzo $Z$, et al. The challenge of reform: 10 years of curricula change in Italian medical schools. Med Teach 2009;31:1047-55. [CrossRef]

2. Cumming A, Ross M. The Tuning Project for Medicine - learning outcomes for undergraduate medical education in Europe. Med Teach 2007;29:636-41 [CrossRef]

3. Brokaw JJ, Torbeck LJ, Bell MA, Deal DW. Impact of a competency-based curriculum on medical student advancement: a tenyear analysis. Teach Learn Med 2011;23:207-14 [CrossRef]

4. Oda Y, Koizumi K. Status of medical education reform at Saga Medical School 5 years after introducing PBL. Kaohsiung J Med Sci 2008;24(3 Suppl):S46-53. [CrossRef]

5. Xiao H, Xian L, Yu X, Wang J. Medical curriculum reform in Sun Yat-sen University: implications from the results of GMER evaluation in China. Med Teach 2007;29:706-10. [CrossRef]

6. Tomorrow's Doctors Outcomes and standards for undergraduate medical education, General Medical Council 2009, http://www. gmc-uk.org/TomorrowsDoctors_2009.pdf_39260971.pdf, (Available from, 2012 July 26).

7. Frank, JR. The CanMEDS 2005 physician competency framework. Better standards. Better physicians. Better care. Ottawa: The Royal College of Physicians and Surgeons of Canada, 2005.

8. Chu TS, Weed HG, Wu CC, Hsu HY, Lin JT, Hsieh BS. A Programme of accelerated medical education in Taiwan. Med Teach 2009;31:e74-8 [CrossRef]

9. Yllmaz ED. Education Systems and Teaching Methods in Medical Education and Responsibility of Medical Schools. Trakya Univ Tip Fak Derg 2006;23:1-3

10. Official Journal of the European Union, 3.9.2005, Section 2, Article 24, http://eur-lex.europa.eu/LexUriServ/LexUriServ.do?uri=OJ:L:20 05:255:0022:0142:en:PDF, (Available from: 2012 July 26).

11. Promes SB, Chudgar SM, Grochowski COC, Shayne P, Isenhour J, Glickman SW, et al. Gaps in procedural experience and competency in medical school graduates. Acad Emerg Med 2009;16:S58-62. [CrossRef] 
12. Swiss Catalogue of Learning Objectives for Undergraduate Medical Training, http://sclo.smifk.ch/downloads/sclo_2008.pdf, (Available from, 2013 February 27).

13. Bulut A. A News: National Undergraduate Medical Core Curriculum has been composed. Tıp Eğitimi Dünyası 2003;13:13-36.

14. Özgün Ş, Topbaş M, Çan G. KTU Medical Faculty's Interns Self Reported Competence About Diagnostic And Therapeutic Skills for Selected Diseases and Emergency Situations as well as their Application of Selected Invasive and Non-Invasive Procedures. Tıp Egitimi Dünyası 2006;21:11-5.

15. Göçgeldi E, İstanbulluoglu H, Koçak N, Ceylan S, Çetin M, Uçar M. Do The Final Year Medical Students Consider Themselves Competent Enough To Work In Primary Health-Care Services? Tıp Egitimi Dünyası 2011;31:29-37.

16. Sayek I, Odabaşı O, Kiper N. Report of Undergraduate Medical Education Turkish Medical Association 2010. TTB Yayınları, Ankara, 2010.

17. Hannon FB. A national medical education needs' assessment of interns and the development of an intern education and training programme. Med Educ 2000;34:275-84. [CrossRef]

18. European Core Curriculum the Students' Perspective, 5th International Follow-Up Conference on the Bologna Process in Medical Education, 6 - 10th July, 2006, Bristol (UK), http://www.educmed.net/pdf/documentos/bolonia/eccsp.pdf, (Available from, 2012 July 26).
19. Martins HMG, Detmer DE, Rubery E. Perspectives on management education: an exploratory study of UK and Portuguese medical students. Med Teach 2005;27:493-8. [CrossRef]

20. Sanders CW, Edwards JC, Burdenski TK. A survey of basic technical skills of medical students. Acad Med 2004;79:873-5. [CrossRef]

21. Wu EH, Elnicki DM, Alper EJ, Bost JE, Corbett EC, Fagan MJ, et al. Procedural and interpretive skills of medical students: experiences and attitudes of third-year students. Acad Med 2006;81(10 Suppl):S48-51. [CrossRef]

22. Brennan N, Corrigan O, Allard J, Archer J, Barnes R, Bleakley A, et al. The transition from medical student to junior doctor: today's experiences of Tomorrow's Doctors. Med Educ 2010;44:449-58. [CrossRef]

23. Harris P, Snell L, Talbot M, Harden RM. Competency-based medical education: implications for undergraduate programs. Med Teach 2010;32:646-50. [CrossRef]

24. Frank JR, Snell LS, Cate OT, Holmboe ES, Carraccio C, Swing SR, et al. Competency-based medical education: theory to practice. Med Teach 2010;32:638-45. [CrossRef]

25. Directive of Turkish Public Health Institution http://www.turkiyehalksagligi.gov.tr/tr/dosya/yonerge_10042012.pdf, (Available from, 2012 July 25).

26. Özçakır A. Should communication and clinical skills training be given in medical education ? Opinions of the intern students. T Klin J Med Sci 2002;22:185-9. 